\title{
COMPARISON BETWEEN ONLINE AND OFFLINE TRAINING IN IMPROVING KNOWLEDGE TOWARD COVID-19 PREVENTION IN COVID-19 VOLUNTEER
}

\author{
Victoria Sari' ${ }^{1}$, Lely Pangesti1), Vitri Widyaningsih ${ }^{2)}$ \\ 1)Masters Program in Public Health, Universitas Sebelas Maret \\ 2)Faculty of Medicine, Universitas Sebelas Maret
}

\begin{abstract}
Background: With the increasing use of technology and current COVID-19 pandemic situation, online training has become a common learning method. The effectiveness of online training is influenced by many factors. Some factors create barriers for online training, such as administrative issues, social interaction, technical skills, motivation, time, technical problems, cost and access to the internet. Other factors could result in low-quality online training, for example an ineffective design and arrangement of multimedia materials. The purpose of this study was to examine comparison between online and offline training in improving knowledge toward COVID-19 prevention in COVID-19 volunteer.

Subjects and Method: A randomized controlled trial was conducted in Klaten, Central Java. A sample of 55 COVID-19 volunteers was selected for this study. A day offline training was attended by 21 volunteers, meanwhile 34 volunteers attended online training. The dependent variable was knowledge. The independent variable was training. Their knowledge toward COVID-19 prevention before and after training was measured by a questionnaire. The data were analyzed by independent t-test.

Results: Mean of volunteer's knowledge after offline training (Mean=8.38; $\mathrm{SD}=0.80$ ) was higher than online training group (Mean= 7.47; $\mathrm{SD}=1.13$ ) and it was statistically significant $(\mathrm{p}=0.002)$.

Conclusion: Offline training is more effective than online training to improve knowledge toward COVID-19 prevention in volunteers.
\end{abstract}

Keywords: knowledge, COVID-19 volunteer, training

\section{Correspondence:}

Victoria Husadani Permata Sari. Masters Program in Public Health, Universitas Sebelas Maret. Jl. Ir. Sutami 36A, Surakarta, 57126, Central Java. Email: victoriahusadani@students.uns.ac.id. Mobile: o81393539020. 